\title{
The Effect of Giving Croton Leaf Crude Extract (Codiaeum variegatum) as an Alternative to The Antibacterial of Edwardsiella tarda in Vitro
}

\author{
Annisa Isti Fauziyyah ${ }^{1 *}$, Arief Prajitno ${ }^{1}$, Mohammad Fadjar ${ }^{1}$, Arif Syaifurrisal ${ }^{1}$ and \\ Farid Muchtar Riyadi ${ }^{1}$ \\ ${ }^{1}$ Aquaculture Study Program, Faculty of Fisheries and Marine Sciences, Brawijaya University, Jl. \\ Veteran, Ketawanggede, Kec. Lowokwaru, Malang City, East Java 65145, Indonesia
}

*Correspondence : annisaistif8@gmail.com

Received : 2021-01-27

Accepted : 2021-06-11

Keywords :

Croton leaf crude extract ( $C$. variegatum), E. tarda bacteria, Inhibition test

\begin{abstract}
Production problems related to aquaculture cannot be separated from diseases that can cause death in fish. Efforts to overcome the bacterial disease Edwardsiella tarda can be done by using natural materials such as the leaves of croton (Codiaeum variegatum). This study aimed to analyze the content of active compounds contained in croton leaf extract which is antibacterial against $E$. tarda bacteria. Inhibition test was performed by dilution method Minimum Inhibition Concentration (MIC test) and agar diffusion (disc test). The MIC test used five concentrations: $1 \mathrm{mg} / \mathrm{L}, 10 \mathrm{mg} / \mathrm{L}, 100$ $\mathrm{mg} / \mathrm{L}, 500 \mathrm{mg} / \mathrm{L}$, and $1000 \mathrm{mg} / \mathrm{L}$ on Tryptone Soy Broth (TSB) media, while the disc test used five doses of croton leaf extract, namely: A $(100 \mathrm{mg} / \mathrm{L}), \mathrm{B}(200 \mathrm{mg} / \mathrm{L}), \mathrm{C}(300 \mathrm{mg} / \mathrm{L})$, D (400 mg/L) and E (500 mg/L), 2 controls (positive and negative), and three replications on Tryptone Soy Agar (TSA) media and incubated for $2 \times 24 \mathrm{~h}$. The positive control used chloramphenicol $(5 \mathrm{mg} / \mathrm{L})$ antibiotic. Croton leaf extract contains several compounds, namely saponins, flavonoids, tannins, steroids, and polyphenols, which are antibacterial and could kill the test bacteria with the highest average inhibition zone results obtained at a dose of $\mathrm{E}(500 \mathrm{mg} / \mathrm{L})$ of $6.34 \mathrm{~mm}$, while the lowest results were obtained at dose A $(100 \mathrm{mg} / \mathrm{L})$ of $3.12 \mathrm{~mm}$.
\end{abstract}

\section{INTRODUCTION}

One of the obstacles for fish farmers is a disease caused by bacteria. One of the bacterial diseases that are an obstacle to fish farming is the one caused by the Edwardsiella tarda bacteria. E. tarda bacteria are included in the Enterobacteriaceae family, which is a Gram-negative group of bacteria and is motile because it has peritrichous flagella. Murwantoko et al. (2019), said that these bacteria are $1 \mu \mathrm{m} \times 2-3 \mu \mathrm{m}$ in size, are in the form of short rods, are non-acid fast, do not have spores, and do not have a capsule. E. tarda bacteria are facultatively anaerobic, glucose fermentation but negative in lactose, oxidase-negative, and catalase-positive fermentation. A'yunin et al. (2020) explained that E. tarda bacteria is the cause of MES (Motile Edwardsiella Septicemia). E. tarda infection causes a decrease in the productivity of fish culture, causing losses for farmers. Efforts to overcome infectious diseases such as $E$. tarda bacteria can be done by using 
antibiotics, but according to Rosidah and Afizia (2012), these antibiotics will increase the frequency of bacterial isolates that are resistant to antibiotics and the occurrence of accumulation which will endanger environmental health.

One of the other treatment efforts to treat bacterial diseases is the use of bioactive materials from plants. Natural ingredients that can be used in E. tarda bacteria are guava leaf extract (Psidium guajava L.), Rhizophora sp. leaf extract, and red ginger extract (Zingiber officinale var. Rubrum) (Setyowati et al., 2014; Syawal et al., 2017; Prastiti et al., 2015). The alternative medicine is the leaf part of the croton plant (C. variegatum). Croton leaves contain several compounds, namely saponins, flavonoids, tannins, steroids, and polyphenols (Amalia et al., 2014). The antibacterial content is generally able to disrupt the membrane permeability of bacterial cells and cause bacterial lysis so that it is thought to be able to treat fish infected with these bacteria.

Research on the potential of croton leaf extract (C. variegatum) as an antibacterial was last published in 2020 which was applied to other bacteria, namely Escherichia coli. The use of croton leaf extract (C. variegatum) to inhibit $E$. tarda bacteria has never been done either in vitro or in vivo.

This study aimed to analyze the content of active compounds contained in croton leaf extract which is antibacterial against $E$. tarda bacteria.

\section{METHODOLOGY}

\section{Place and Time}

This research was conducted at the Fish Cultivation Laboratory, Fish Disease and Health Division (Faculty of Fisheries and Marine Sciences, Brawijaya University), from December 2020 to January 2021.

\section{Research Materials}

The materials used in this study include Edwardsiella tarda bacteria obtained from the Fish Quarantine
Standard Test Center, Quality Control and Fishery Product Safety (BUSKIPM), Jakarta, croton cobra leaves (C. variegatum A. Juss) from Technical Implementation Unit (UPT) Materia Medica Batu, Malang, the solvent for maceration is ethanol with pro-analysis quality (PA), filter paper with the trademark Whatman No. 42, aluminum foil and plastic wrap, DMSO, Aquades, alcohol, disc paper with a diameter of 6 $\mathrm{mm}$, and culture media namely Tryptone Soy Agar (TSA) and Tryptone Soy Broth (TSB).

Puring leaves contain several compounds, namely in the form of saponins, flavonoids, tannins, steroids, and polyphenols (Amalia et al., 2014). This compound is believed to act as an antibacterial agent by inactivating enzymes, affecting cell membrane function, denaturing proteins, and can damage cell walls due to decreased permeability. Changes in the permeability of the cytoplasmic membrane result in disruption of the transportation of crucial organic ions into the cell, thereby inhibiting growth and even cell death. So, it is hoped that it can repair damage to blood cells and tissues of gourami ( $O$. gouramy).

Bacterial culture procedure according to Budianto et al. (2015), the first thing to do is to prepare $5 \mathrm{ml}$ of TSA media and put it in a test tube. The media was then sterilized in an autoclave for 15 minutes at a temperature of $121{ }^{\circ} \mathrm{C}$ and a pressure of $1 \mathrm{~atm}$. The process of planting pure cultures of E. tarda bacteria was taken aseptically, then put into the prepared TSA media, the TSA media which already contained bacteria were then incubated in an incubator at a temperature of $300 \mathrm{C}$ for 24 hours so that the results of the initial bacterial density were obtained using the Optical Density method (OD) and Total Plate Count (TPC) of $3.46 \times 10^{15}$ cells $/ \mathrm{ml}$. The readings are made visually. The calculation of the number of microbes used is through the TPC method. From the TPC results, the number of bacteria that can be used in the 
antibacterial activity test is $10^{15} \mathrm{CFU} / \mathrm{ml}$. This MIC test is considered to be the lowest drug concentration of an antibacterial agent that inhibits the total growth of microorganisms. The MIC test was carried out using 7 test tubes using TSB media, E. tarda bacteria, and croton leaf extract dissolved in DMSO 10\%.

\section{Research Design}

The research method used in this research is the experimental method. The research design used a completely randomized design (CRD). CRD is the simplest design when compared to other designs. In this design, there is no local control so that the only sources of diversity observed are treatment and errors. This study used the independent variables in the form of croton leaf extract and the active compound in isolation as the dependent variable. The number of treatments in this study was seven concentrations with two types of control, namely positive control and negative control, and three replications.

\section{Work Procedure}

In this study, the equipment used included Rotary Evaporator Vacuum, refrigerator, autoclave, petri dish, Erlenmeyer $(250 \mathrm{ml}, 500 \mathrm{ml}$, and 1000 $\mathrm{ml}$ ), beaker glass $(500 \mathrm{ml}$ and $1000 \mathrm{ml})$, micropipette, drop pipette, volume pipette, loop needles, Bunsen burners, Bunsen, test tubes, test tube racks, measuring cups $(10 \mathrm{ml}, 50 \mathrm{ml}$, and 100 $\mathrm{ml}$ ), funnels, spatulas, digital scales, analytical scales, hot plates, and magnetic stirrers.

The extraction process is an important first step in medicinal plant research because the plant extract preparation is the starting point for the isolation and purification of the chemical components contained in plants. Dry simplicial that has been mashed is then extracted by maceration using 96\% ethanol solvent (Febrina et al., 2015). By the research of Ogunwenmo et al. (2007), where 500 grams of croton leaf powder is put into 2 jars, in each jar is filled with 250 grams of croton leaf powder and soaked using 96\% ethanol solvent with a ratio of 1: 10 as much as 5 liters with each jar filled 2.5 liters for $2 \times 24$ hours at room temperature $\left(27-30^{\circ} \mathrm{C}\right)$. The solution obtained is then filtered with filter paper to separate the solution from the precipitate, then the result of the maceration solution is evaporated with a Rotary Vacuum Evaporator and awaited, resulting in a crude extract of croton leaves that is shaped like a paste.

Inhibition test was performed by dilution method (MIC test) and agar diffusion (disc test). The purpose of the MIC test is to test the minimum concentration that can inhibit bacterial growth by more than $90 \%$. The MIC test used 5 concentrations: $1 \mathrm{mg} / \mathrm{L}, 10 \mathrm{mg} / \mathrm{L}$, $100 \mathrm{mg} / \mathrm{L}, 500 \mathrm{mg} / \mathrm{L}$, and $1000 \mathrm{mg} / \mathrm{L}$ on TSB media. The positive control used chloramphenicol antibiotics at $5 \mathrm{mg} / \mathrm{L}$. Meanwhile, the disc test method according to Ekklesia et al. (2020), namely the test bacterial suspension is spread using a triangle on the media and after that, a disc paper is placed on top of it which has been soaked in each concentration of leaf ethanol extract for approximately 15 minutes. After being incubated at $37^{\circ} \mathrm{C}$ for $2 \times 24$ hours, the formed inhibition zone was observed and measured. Disc test using 5 treatment concentrations of croton leaf extract, namely: A (100 mg/L), B (200 mg/L), C (300 mg/L), D (400 mg/L) and E (500 $\mathrm{mg} / \mathrm{L}$ ), 2 controls (positive and negative), and 3 replicates on TSA media.

\section{Data Analysis}

Based on the research results obtained from the inhibition zone or clear zone giving extract of croton leaves against E. tarda bacteria, statistical data analysis was carried out using variability analysis or $\mathrm{F}$ test Analysis of Variance (ANOVA) by the design used, namely completely randomized design (CRD). To determine the form of the relationship between the treatments and the inhibition 
zone (test parameters), the orthogonal polynomial test is used which provides information on the effect of the best information.

\section{RESULTS AND DISCUSSION Minimum Inhibitory Concentration (MIC Test)}

The MIC test was carried out using puring leaf extract as an antibacterial in several concentrations (ppm) which aims to determine the minimum concentration that can inhibit the growth of E. tarda bacteria. Determining the dose of puring leaf extract by measuring the turbidity value at graded dose levels and bacterial substances through the optical density (OD) value using a Spectrophotometer with a wavelength of $615 \mathrm{~nm}$. Observations were made on a spectrophotometer to measure Optical Density The MIC test results in this study are presented in Table 1.

Table 1. MIC test results.

\begin{tabular}{lll}
\hline No. & Concentration $(\mathrm{mg} / \mathrm{L})$ & Absorbance \\
\hline 1. & Control $(-)$ & 0,573 \\
2. & 1 & 0,204 \\
3. & 10 & 0,382 \\
4. & 100 & 0,189 \\
5. & 500 & 0,227 \\
6. & 1000 & 0,223 \\
7. & Control $(+)$ & 0,049 \\
\hline
\end{tabular}

Note: $\quad$ Positive control using chloramphenicol antibiotic $(5 \mathrm{mg} / \mathrm{L})$, negative control without treatment only bacteria.

The MIC test results above indicate that the leaf extract of croton (C. variegatum) has an inhibitory power against the growth of E. tarda bacteria, where the minimum concentration of inhibition is 0.189 at a concentration of $100 \mathrm{mg} / \mathrm{L}$. In the negative control, the highest value was obtained, namely 0.573 , this means that the negative control could not inhibit the growth of $E$. tarda bacteria because it was not treated with croton leaf extract (C. variegatum) or antibiotics. The increase in absorbance value after a dose of $100 \mathrm{mg} / \mathrm{L}$ indicates that there is the bacterial resistance to puring leaf extract because at a dose of $100 \mathrm{mg} / \mathrm{L}$ it has shown the first lowest value or the best from other doses. The minimum inhibitory concentration is the lowest concentration of antibiotics that will inhibit the growth of microscopic microorganisms (Budianto et al., 2015). From the data above, croton leaf extract (C. variegatum) with a concentration of $100 \mathrm{mg} / \mathrm{L}$ was chosen as the reference for the minimum dose to determine the concentration of the disc test.

\section{Antibacterial Activity}

Before discussing the antibacterial activity, the $\mathrm{LC}_{50}$ test can be carried out to determine the effective dose for use in the antibacterial test. A toxicity test $\left(\mathrm{LC}_{50}\right)$ is a preliminary test to determine the toxicity of a substance in test animals so that the dose of the substance can be effective which can kill $50 \%$ of the population of test animal organisms. The potential toxicity of a chemical is often shown as the $\mathrm{LC}_{50}$. The results of the toxicity test obtained were that at a dose of 100-300 $\mathrm{mg} / \mathrm{L}$ it could be said that it was not so toxic because there were no dead fish. The dose of $400 \mathrm{mg} / \mathrm{L}$ experienced the death of 1 fish at the 48th hour and the dose of $500 \mathrm{mg} / \mathrm{L}$ experienced the death of $50 \%$, namely 2 fish that died at the 96th hour. So, the dose to be used in the second phase of the study is more than $500 \mathrm{mg} / \mathrm{L}$.

Based on the results of observations during the study regarding the effect of giving croton leaf extract as an antibacterial alternative to $E$. tarda, it was shown that the size of the inhibition zone formed in each treatment was different, 
depending on the number of doses given.

Inhibition test results data from croton leaf extract can be presented in Table 2 .

Table 2. Data from the test results of the inhibition of croton leaf extract (C. variegatum).

\begin{tabular}{|c|c|c|c|c|c|}
\hline \multirow{2}{*}{ Treatment } & \multicolumn{3}{|c|}{ Repetition } & \multirow{2}{*}{ Total } & \multirow{2}{*}{ Mean \pm STDV } \\
\hline & 1 & 2 & 3 & & \\
\hline A & 3.37 & 2.95 & 3.17 & 9.49 & $3.6 \pm 0,21$ \\
\hline B & 3.49 & 3.46 & 3.21 & 10.16 & $3.39 \pm 0,15$ \\
\hline C & 4.02 & 4.97 & 4.61 & 13.6 & $4.53 \pm 0,48$ \\
\hline D & 4.24 & 4.98 & 5.12 & 14.34 & $4.78 \pm 0,47$ \\
\hline E & 4.98 & 5.12 & 6.34 & 16.44 & $5.48 \pm 0,75$ \\
\hline Control (+) & 14.15 & 13.96 & 14.05 & 42.16 & $14.05 \pm 0,10$ \\
\hline Control (-) & 0.00 & 0.00 & 0.00 & 0.00 & $0.00 \pm 0.00$ \\
\hline Total & 34.25 & 35.44 & 36.5 & 106.19 & \\
\hline
\end{tabular}

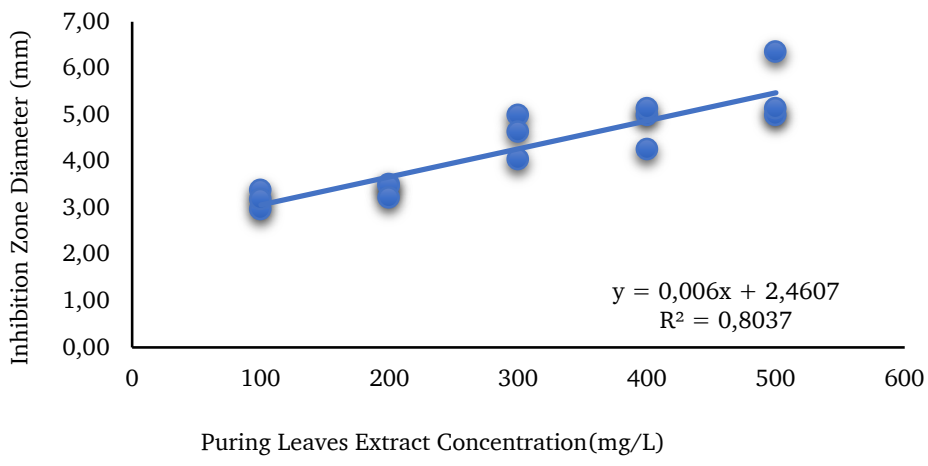

Figure 1. Antibacterial activity of croton leaf extract (C. variegatum) against E. tarda bacteria.

Table 2 above presents the results of the inhibition zone diameter $(\mathrm{mm})$ at different concentrations of $E$. tarda bacteria. Table 2 shows that with the increasing concentration of croton leaf extract, the inhibition zone diameter also increased. This shows that croton leaf extract has antibacterial compounds that can inhibit bacterial growth, where the highest average inhibition zone results were obtained at concentration E (500 $\mathrm{mg} / \mathrm{L}$ ) of $5.48 \pm 0.75 \mathrm{~mm}$, while the lowest results were obtained at concentration A $(100 \mathrm{mg} / \mathrm{L})$ of $3.16 \pm$ $0.21 \mathrm{~mm}$. According to Salni et al. (2016), the classification of the inhibition zone diameter is categorized as follows: weak $\leq$ $5 \mathrm{~mm}$, moderate $5-10 \mathrm{~mm}$, strong $10-20$ $\mathrm{mm}$.

While the results of the inhibition zone test on the negative control did not produce an inhibition zone, because the solution used was distilled water which did not have antibacterial compounds. Meanwhile, the inhibition zone diameter produced by positive control chloramphenicol showed a difference with a mean value of $14.05 \pm 0.10 \mathrm{~mm}$, this is because chloramphenicol is a bacteriostatic antibiotic chemical. Observations are made by measuring the vertical and horizontal diameters in millimeters $(\mathrm{mm})$ using a caliper so that they can be called the zone of drag. The difference in the area of the inhibition zone formed can be seen from the zone variations in each experimental material. This difference is caused by several factors, including the size of the inoculum, incubation time, extract concentration and the antibacterial power of the nutritious substance.

In the data above, E. tarda bacteria are only bacteriostatic, which means that croton leaf extract can only inhibit bacterial growth, this is based on 
observations for 24 hours which show that the dose is only able to inhibit the growth of $E$. tarda bacteria by inhibiting protein synthesis by binding ribosome of an organism. Putri et al. (2019), stated that the bond was not so strong that when the concentration and stability decreased, the antimicrobials would release ribosomes which resulted in bacteria being able to grow back.

The mechanism of action of antibacterial is classified into four main things, namely, inhibition of cell wall synthesis, inhibition of cell membrane function, inhibition of protein synthesis, and inhibition of nucleic acid synthesis. According to Dhuha et al. (2016), several active compounds are antibacterial, including flavonoids, tannins, saponins, and phenols. The antibacterial effect is due to the compounds contained in organisms damaging the cell walls and affecting their integrity.

In the research of Bijekar and Gayatri (2014), it is revealed that croton leaves are rich in flavonoids, phenols, and terpenoids. Qualitative phytochemical test results were obtained, namely alkaloids in the range $(4,66-10,2 \%)$, flavonoids $(33,1$ - 37,63\%), saponins $(11,36-13,76 \%)$, phenolic $(35,43-39,76 \%)$, tannins $(10,5$ - 15,32\%), and terpenoids (27,56 $30,3 \%)$. Here it can be concluded that phenolic compounds have the highest value in the crude extract of croton leaves. Phenolic compounds have been shown to inhibit cyclooxygenase and lipoxygenase pathways. Phenolic compounds can also act as chemo preventive or stimulate inhibition of the cell cycle or apoptosis. The damage that can occur to microbial cells due to the administration of croton leaf extract is the inhibition of cell wall synthesis. It is based on the presence of phenol compounds. This is supported by Brewster et al. (1991), that phenol can also cause cell wall damage. Phenols bind to proteins through hydrogen bonds, causing the protein structure to be damaged. Most of the structure of the cell wall and cytoplasmic membrane of bacteria contain protein and fat.
The alkaloid compounds produced by croton leaf extract have the potential as antibacterial because they can damage cell walls. The mechanism of action of alkaloids as antibacterial is predicted through inhibition of cell wall synthesis which will cause cell lysis so that the cells will die (Nimah et al., 2012).

Tannin compounds act as antibacterial. The mechanism of tannin inhibition is using bacterial walls that have been lysed due to flavonoid compounds, causing tannin compounds to easily enter bacterial cells and coagulase the protoplasm of bacterial cells (Devi and Mulyani, 2017).

\section{CONCLUSION}

Based on research on the effect of giving croton leaf extract (C. variegatum) as an in vitro alternative to $E$. tarda antibacterial, it can be concluded that the best treatment was at a concentration of $600 \mathrm{mg} / \mathrm{L}$ and croton leaf extract can be used as an alternative medicinal ingredient as an antibacterial agent against $E$. tarda bacteria by inhibiting the growth of $E$. tarda according to bacteriostatic properties. This has been proven by the presence of a clear zone around the disc paper which has been tested on E. tarda bacteria from croton leaf extract. The clear zone indicates sensitivity and antibacterial activity against croton leaf extract.

Based on the results of the study, it is suggested to utilize other parts (stems, roots, flowers) in croton plants, then further research is needed through in vivo tests to prove the effectiveness of these materials in cultivated organisms infected with E. tarda bacteria.

\section{ACKNOWLEDGMENT}

Researchers realize that this article will not be finished without prayer, support, and encouragement from various parties. On this occasion, the researchers would like to thank: Prof. Dr. Ir. Arief Prajitno, MS and Dr. Ir. Muhammad Fadjar, M.Sc. as the supervisor, and my 
two colleagues Arif Syaifurrisal and Farid Muchtar Riyadi.

\section{REFERENCES}

A'yunin, Q., Budianto, Andayani, S. and Pratiwi, D.C., 2020. Analisis kondisi kesehatan ikan patin Pangasius sp. yang terinfeksi bakteri Edwardsiella tarda. Journal of Aquaculture and Fish Health, 9(2), pp.164-172. http://dx.doi.org/10.20473/jafh.v9 i2.16192

Amalia, N.P., Syamsidar, H.S. and Ramadani, K., 2014. Biosorpsi tanaman puring (Codiaeum variegatum) terhadap emisi timbal $(\mathrm{Pb})$ pada kendaraan bermotor. AlKimia, 2(2), pp.69-79. https://doi.o $\mathrm{rg} / 10.24252 /$ al-kimia.v2i2.1654

Bijekar, S.R. and Gayatri, M.C., 2014. Phytochemical profile of Codiaeum variegatum (L.) BI. International Journal of Pharmacology and Pharmaceutical Sciences, 2(3), pp.22-31. https://www.academia.e du/13791653/Phytochemical_profil e_of_Codiaeum_variegatum_L_Bl

Brewster, M.E., Doerge, D.R., Huang, M.J., Kaminski, J.J., Pop, E. and Bodor, N., 1991. Application of semiempirical molecular orbital techniques to the study of peroxidase-mediated oxidation of phenols, anilines, sulfides, and thiobenzamides. Tetrahedron, 47(36), pp.7525-7536. https://doi. org/10.1016/S0040-4020(01)8827 7-6

Budianto, Prajitno, A. and Yuniarti, A., 2015. Aktivitas antibakteri ekstrak buah adas (Foeniculum vulgare, Mill) pada Vibrio harveyi dan Vibrio alginolyticus. agriTECH, 35(3), pp.266-272. https://doi.org/10.221 46/agritech.9336

Devi, S. and Mulyani, T., 2017. Uji aktivitas antibakteri ekstrak etanol daun pacar kuku (Lawsonia inermis Linn) pada bakteri Pseudomonas aeruginosa. Journal of Current Pharmaceutical Sciences, 1(1), pp.30-35. https://journal.umbjm.ac .id/index.php/jcps/article/view/80

Dhuha, S., Bodhi, W. and Kojong, N., 2016. Aktivitas antibakteri ekstrak etanol daun lamun (Syiringodium isoetifolium) terhadap bakteri Pseudomonas aeruginosa. Pharmacon, 5(1), pp.231-237. https: //doi.org/10.35799/pha.5.2016.11 246

Ekklesia, L.P., Astuty, E. and Huliselan, I., 2020. Antibacteria Activity of Ethanol Extract Gandaria Leaf (Bouea macrophylla Griff) Against Staphylococcus aureus and Escherichia coli. Journal of Current Pharmaceutical Sciences, 3(2), pp.229-233. https://journal.umbjm. ac.id/index.php/jcps/article/view/ 477

Febrina, L., Rusli, R. and Muflihah, F., 2015. Optimalisasi ekstraksi dan uji metabolit sekunder tumbuhan libo (Ficus variegate blume). Journal of Tropical Pharmacy and Chemistry, 3(2), pp.74-81. https://doi.org/10. 25026/jtpc.v3i2.153

Murwantoko, Diniarti, E. and Triyanto, 2019. Isolation, Characterization and Pathogenicity of Edwardsiella tarda a Causative Disease on Freshwater Fish in Yogyakarta. Jurnal Perikanan, 21(1), pp.41-45. https://doi.org/10.22146/jfs.39920

Nimah, S., Ma'ruf, W.F. and Trianto, A., 2012. Uji bioaktivitas ekstrak teripang pasir (Holothuria scabra) terhadap bakteri Pseudomonas aeruginosa dan Bacillus cereus. Jurnal Pengolahan dan Bioteknologi Hasil Perikanan, 1(2), pp.1-9. https://ejournal3.undip.ac.id/index .php/jpbhp/article/view37

Ogunwenmo, K.O., Idowu, O.A., Innocent, C., Esan, E.B. and Oyelana, O.A., 2007. Cultivars of Codiaeum variegatum (L.) Blume (Euphorbiaceae) show variability in phytochemical and cytological characteristics. African Journal of Biotechnology. 6(20), pp.2400-2405. 
https://doi.org/10.5897/AJB2007. 000-2376

Prastiti, L.A., Sarjito, and Prayitno, S.B., 2015. Pengaruh penambahan ekstrak jahe merah (Zingiber officonale var. Rubrum) pada media pemeliharaan terhadap kelulus hidupan dan pertumbuhan ikan gurami (Osphronemus gouramy) yang diinfeksi bakteri Edwardsiella tarda. Journal of Aquaculture Management and Technology, 4(3), pp.31-37. https://ejournal3.undip.a c.id/index.php/jamt/article/view/9 459/9185

Putri, N.M.M.S., Kandou, F.E.F. and Singkoh, M., 2019. Phytochemical screening test the antibacterial bioactivity of gorgonia Mopsella sp.* cf, Siphonogorgia sp. and Villogorgia sp. Againts Pseudomonas aeruginosa and Bacillus cereus), JURNAL BIOS LOGO 9(2), pp.83-90. https://doi.or $\mathrm{g} / 10.35799 / \mathrm{jbl}$.9.2.2019.24749

Rosidah and Afizia, W.M., 2012. Potensi ekstrak daun jambu biji sebagai antibacterial untuk menanggulangi serangan bakteri Aeromonas hydrophila pada

ikan gurame (Osphronemous gourami lacepede). Jurnal Akuatika, 3(1), pp.19-27.

http://jurnal.unpad.ac.id/akuatika/ article/view/473/565

Salni, Marisa, H. and Harmida, 2016. Activity tests of bioactive material of salung leaf (Psychotria viridiflora Reinw. Ex. Blume) against Salmonella thypi bacteria in vitro and in vivo. Jurnal Ilmu Kefarmasian Indonesia, 14(1), pp.13-18. http://ji fi.farmasi.univpancasila.ac.id/index .php/jifi/article/view/41

Setyowati, E., Prayitno, S.B. and Sarjito, 2014. Pengaruh perendaman ekstrak daun jambu biji (Psidium guajava L.) terhadap kelulus hidupan dan histopatologi hati ikan patin (Pangasius hypophtalamus) yang diinfeksi bakteri Edwardsiella tarda. Journal of Aquaculture Management and Technology, 3(4), pp.174-182. https://ejournal3.undi p.ac.id/index.php/jamt/article/vie $\mathrm{w} / 6669$

Syawal, H., Karnila, R., Dirta, A. and Kurniawan, R., 2017. Rhizopora sp. Leaf Extract Inhibits the Growth of Streptococcus agalactiae and Edwardsiella tarda. Jurnal Veteriner, 18(4), pp.604-609. https://doi.org/ 10.19087/jveteriner.2017.18.4.604 